\title{
Study of organoleptic and technological properties of minced meat products with addition of mushroom powder
}

\author{
Tetiana Stepanova ${ }^{1 *}$, and Naaja A. Akrashie ${ }^{1}$ \\ ${ }^{1}$ Department Technology of Nutrition, Sumy National Agrarian University, Sumy, Ukraine
}

\begin{abstract}
The authors propose a new type of minced meat products with the addition of dry mushrooms in powder form. It provides high protein content and good taste of finished products. The article presents the results of experimental studies on the enrichment of minced meat products with mushroom powder. Tasting analysis showed that the best organoleptic indicators have samples of culinary products with the content of enriched mushroom powder in $10 \%$. A further increase above $15 \%$ adversely affects the organoleptic characteristics of the finished culinary products. Adding of mushroom powder to the amount of minced meat products allowed to improve consumer properties, reduce calorie content, as well as produce functional products.
\end{abstract}

\section{Introduction}

Food is an integral part of human life. The search and involvement in the technological process of raw materials that have a balanced chemical composition and have a functional effect is the key to creating high-quality food products that have a beneficial effect on the human body. Combination of various types of raw materials for achieve a certain type of nutrient, micro- and macroelement, vitamin, fatty acid balance is one way of technology development. Cultivated mushrooms have a balanced composition of nutrients, they also grow quickly, without requiring expensive equipment for growing, are easily processed, have a pleasant taste and aroma when ready [1]. Therefore, such raw materials can cope the protein deficiency, that remains as a major problem for humanity. Mushrooms have antioxidant, antitumor and antiinflammatory properties [2]. Thereby, the use of dry mushrooms in powder form in the technology of minced meat products as an alternative source of protein and nutrients is very relevant.

\section{Experimental}

The aim of research is the analysis of organoleptic and technological properties of minced meat products with addition of powdered cultivated edible mushrooms for enrichment such meat products with functional ingredients.

Edible cultivated mushrooms are widely represented on the modern market, such as (Agaricus bisporus bicuspid champignons, Brazilian champignon Agaricus subrufescens, Common oyster mushroom Pleurotus ostreatus, Flamulin or Enokitake Flammulina velutipes, Edible lentil or shiitodedes etc.). The nutritional value of mushrooms depends on the species, stage of development and environmental conditions [3]. Depending on the species, raw protein content in mushrooms ranges from 12 to $35 \%$. The composition of free amino acids is very different. In general, they are rich in threonine and valine. However, they are poor in sulfur-containing amino acids.

Total carbohydrate content in mushrooms ranges from $26-82 \%$. It based on dry matter in different mushrooms. Carbohydrate profile of mushrooms is represented by starch, pentoses, hexoses and disaccharides. The raw fibrous composition of the fungus consists of the frequently assimilated polysaccharides and chitin.

Edible mushrooms could be a source of many different nutraceuticals such as unsaturated fatty acids, phenolic compounds, tocopherols, ascorbic acid and carotenoids. Thus, they might be used directly in diet and promote health, taking advantage of the additive and synergistic effects of all the bioactive compounds present.

Edible mushrooms have low calorie content. They are usually low in lipids with a higher proportion of polyunsaturated fatty acids. Mushrooms do not contain cholesterol, but they have ergosterol, which acts as a precursor to the synthesis of vitamin $\mathrm{D}$ in the human body.

Nutritional value of various types cultivated edible mushrooms, which are planned to be used in the technology of minced meat products, are represented in Table 1 [3].

High nutritional value determines the widespread use of mushrooms in the technology of low-calorie products. As can be seen from the Table I, mushrooms have the low content of fats. Also, they are an alternative source of protein.

Mushrooms take a leading position in terms of protein content compared to vegetables [4]. High biological value of mushrooms proteins is due to the content of essential amino acids. The content of essential amino acids in proteins of fungi compared to the "ideal protein" (Table 2) [2]. 
Table 1. Nutritional value of cultivated edible mushrooms (in dry matter gram per $100 \mathrm{~g}$ ).

\begin{tabular}{|c|c|c|c|c|}
\hline $\begin{array}{c}\text { Kind of } \\
\text { mushrooms }\end{array}$ & Protein & Fat & Carbohydrates & Ash \\
\hline $\begin{array}{c}\text { Agaricus } \\
\text { bisporous }\end{array}$ & 33.48 & 3.10 & 46.17 & 5.70 \\
\hline $\begin{array}{c}\text { Pleurotus } \\
\text { ostreatus }\end{array}$ & 30.40 & 2.20 & 57.60 & 9.80 \\
\hline $\begin{array}{c}\text { Flammulina } \\
\text { velutipes }\end{array}$ & 17.60 & 1.90 & 73.10 & 7.40 \\
\hline $\begin{array}{c}\text { Lentinula } \\
\text { edodes }\end{array}$ & 32.93 & 3.73 & 47.60 & 5.20 \\
\hline $\begin{array}{c}\text { Vovarella } \\
\text { volvaceae }\end{array}$ & 37.50 & 2.60 & 54.80 & 1.10 \\
\hline
\end{tabular}

A significant content of essential amino acids closes to their amount in the "ideal protein", as we can see from the Table 2. It allows us to predict the prospects of using this type of raw material as a source of high-grade protein.

Carbohydrates of mushrooms are predominantly represented by $\beta$-glucans by polymers, as well as chitin, mannan, galactans and xylan [5]. Fungal polysaccharides, as indigestible carbohydrates can act as prebiotics in the human body [6]. They also demonstrate a stable antimicrobial effect against a number of pathogens (Bacillus cereus, Staphylococcus aureus and Salmonella typhimurium) [7].

Cultivated edible mushrooms are good source of vitamins, in particular $\mathrm{B}$ vitamins $\left(\mathrm{B}_{1}, \mathrm{~B}_{2}, \mathrm{~B}_{3}, \mathrm{~B}_{5}\right.$ and $\left.\mathrm{B}_{9}\right)$, vitamins $\mathrm{D}$ and $\mathrm{E}$ [8], as well as minerals (K, Ca, $\mathrm{P}, \mathrm{Na}$, $\mathrm{Mg}$ ) [9].

Turkey meat contains proteins. The amount and ratio of essential amino acids in which is close to ideal indicators. This allows turkey meat to be recognized suitable for the production of minced meat products. The increased level of protein and the lower level of fat in turkey meat allows it to be used in the production of meat products, including dietary ones [10].

For this reason, mushrooms are quite attractive as food ingredients for enrichment, for their nutritional value, safety and affordability.

\section{Results and discussion}

Cultivated edible mushrooms are widely used in the food industry thanks to their high nutritional and biological value.

Thereby, their use in the technology of minced meat products requires the attention and intervention of scientific technologists.

The authors note $[11,12]$ improvement in the quality indicators of the finished product when using edible cultivated mushrooms in the form of a powder in the production of chicken sausages.

We were used mushrooms in powdered form (sample 1) and finely ground mass of cooked mushrooms (sample 2 ) in the proposed technology of minced meat products. As a control we were used poultry cutlet by Collection of recipes for dishes and culinary products [12].

As shown by the research results, the introduction of mushroom powder into minced meat leads to a gradual softening of the mince system. At the same time, it was noted that adding more than $10.0 \%$ of a mushroom additive to the minced meat is undesirable, since this is associated with a decrease in the technological properties of the minced meat system.

Table 2. The content of essential amino acids in proteins of mushrooms, compared with the "ideal protein".

\begin{tabular}{|c|c|c|c|c|c|c|c|c|c|}
\hline \multirow{2}{*}{$\begin{array}{l}\text { Name of } \\
\text { amino acids }\end{array}$} & \multicolumn{9}{|c|}{ Amino acid content, g per $100 \mathrm{~g}$ of protein } \\
\hline & $\begin{array}{l}\text { Perfect } \\
\text { protein }\end{array}$ & $\begin{array}{c}\text { Oyster } \\
\text { mushroom }\end{array}$ & Shiitake & Enoki & $\begin{array}{l}\text { Flammulina } \\
\text { velutipes }\end{array}$ & $\begin{array}{l}\text { Vovarella } \\
\text { volvaceae }\end{array}$ & $\begin{array}{l}\text { Agaricus } \\
\text { bisporus }\end{array}$ & $\begin{array}{c}\text { Pleurotus } \\
\text { eryngii }\end{array}$ & $\begin{array}{c}\text { Straw } \\
\text { mushroom }\end{array}$ \\
\hline $\begin{array}{l}\text { Essential } \\
\text { amino acids }\end{array}$ & 36.0 & 42.7 & 45.7 & 77.9 & 31.6 & 39.4 & 69.3 & 38.8 & 43.8 \\
\hline Valine & 5.0 & 5.0 & 5.2 & 7.1 & 3.0 & 2.7 & 8.1 & 4.3 & 6.3 \\
\hline Isoleucine & 4.0 & 3.8 & 4.7 & 11.9 & 3.6 & 4.0 & 16.4 & 2.3 & 5.3 \\
\hline Luecine & 7.0 & 8.8 & 9.2 & 11.4 & 5.6 & 8.2 & 14.3 & 2.3 & 7.3 \\
\hline Lysine & 5.5 & 5.0 & 5.6 & 15.4 & 3.9 & 5.2 & 13.0 & 0.6 & 6.2 \\
\hline $\begin{array}{l}\text { Methionine } \\
+ \text { Cystine }\end{array}$ & 3.5 & 7.5 & 6.0 & 7.1 & 3.8 & 5.4 & 4.3 & 15.6 & 6.7 \\
\hline Threonine & 4.0 & 4.2 & 4.8 & 7.8 & 3.4 & 5.0 & 4.3 & 3.0 & 5.2 \\
\hline $\begin{array}{l}\text { Phenylalanine } \\
\text { +Tyrosine }\end{array}$ & 6 & 6.9 & 9.0 & 13.7 & 7.1 & 7.0 & 5.6 & 9.7 & 6.7 \\
\hline Tryptophan & 1 & 1.5 & 1.2 & 3.4 & 1.2 & 1.9 & 3.2 & 1.0 & 0.1 \\
\hline $\begin{array}{l}\text { Nonessential } \\
\text { amino acids }\end{array}$ & - & 54.0 & 55.2 & 100.4 & 34.7 & 50.9 & 78.0 & 34.5 & 52.7 \\
\hline Arginine & - & 5.4 & 5.3 & 12.8 & 4.3 & 5.5 & 8.8 & 2.4 & 4.9 \\
\hline Glutamic acid & - & 16.5 & 11.5 & 27.8 & 7.3 & 11.9 & 12.7 & 6.3 & 14.0 \\
\hline Alanine & - & 8.2 & 7.8 & 16.9 & 7.3 & 10.5 & 22.9 & 7.3 & 8.6 \\
\hline Glycine & - & 6.1 & 10.3 & 8.0 & 4.1 & 5.4 & 6.7 & 2.6 & 6.9 \\
\hline $\begin{array}{l}\text { Asparaginic } \\
\text { acid }\end{array}$ & - & 9.8 & 7.8 & 16.9 & 7.3 & 10.5 & 22.9 & 7.3 & 8.6 \\
\hline Proline & - & 1.7 & 3.4 & 12.2 & 1.9 & 3.0 & 8.2 & 7.7 & 2.1 \\
\hline Serine & - & 4.2 & 4.7 & 7.0 & 2.7 & 3.4 & 7.4 & 2.9 & 4.2 \\
\hline Histidine & - & 1.9 & 2.2 & 5.5 & 1.5 & 2.9 & 2.0 & 1.3 & 2.3 \\
\hline
\end{tabular}


The cutlets were prepared according to the traditional technological scheme: preparation of meat and mushroom raw materials, dosage of the powdered and other components according to the recipe, mixing until the components are evenly distributed over the volume of minced meat, molding and breading of cutlets, heat treatment.

Quality control of cutlets, as well as comparison of control and experimental samples, showed that adding up to $10.0 \%$ of mushroom powder (instead of bread) to the recipe has a positive effect on the organoleptic characteristics of the samples.

The values of quality indicators of control and experimental samples are presented in the Table 3 .

Table 3. Organoleptic characteristics of research and control samples.

\begin{tabular}{|c|c|c|c|}
\hline $\begin{array}{l}\text { Parameter } \\
\text { name }\end{array}$ & $\begin{array}{l}\text { Poultry cutlet } \\
\quad \text { (control) }\end{array}$ & $\begin{array}{c}\text { Cutlet } \\
\text { with } \\
\text { mushroom } \\
\text { powder } \\
\text { (sample 1) }\end{array}$ & $\begin{array}{l}\text { Cutlet with } \\
\text { finely } \\
\text { ground } \\
\text { mass of } \\
\text { cooked } \\
\text { mushrooms } \\
\text { (sample 2) }\end{array}$ \\
\hline Appear & \multicolumn{3}{|c|}{$\begin{array}{l}\text { Attractive cutaway appearance, evenly } \\
\text { mixed minced meat }\end{array}$} \\
\hline $\begin{array}{l}\text { Sectional } \\
\text { view }\end{array}$ & \multicolumn{3}{|c|}{$\begin{array}{l}\text { All components of the minced meat are } \\
\text { evenly distributed throughout the volume }\end{array}$} \\
\hline $\begin{array}{l}\text { Smell and } \\
\text { taste }\end{array}$ & $\begin{array}{c}\text { Pleasant, } \\
\text { characteristic } \\
\text { of this } \\
\text { product, } \\
\text { without } \\
\text { strangers, } \\
\text { with the } \\
\text { aroma of } \\
\text { spices, } \\
\text { moderately } \\
\text { salty }\end{array}$ & $\begin{array}{c}\text { Well } \\
\text { defined, } \\
\text { pleasant, } \\
\text { without } \\
\text { extraneous } \\
\text { smacks } \\
\text { and odors }\end{array}$ & $\begin{array}{c}\text { Well } \\
\text { defined, } \\
\text { without } \\
\text { extraneous } \\
\text { smacks and } \\
\text { odors }\end{array}$ \\
\hline Consistency & $\begin{array}{l}\text { Juicy, not } \\
\text { crumbly }\end{array}$ & $\begin{array}{l}\text { Tender, } \\
\text { juicy, not } \\
\text { crumbly }\end{array}$ & $\begin{array}{l}\text { Juicy, not } \\
\text { crumbly }\end{array}$ \\
\hline
\end{tabular}

Tender consistency appeared in sample 1(with the addition of powdered mushrooms). The smell of cutlets with mushroom raw materials was more pleasant. The use of mushroom raw materials in the production of minced meat products did not negatively affect the color of the finished product.

Results of organoleptical scores indicated that cutlets prepared from turkey were rated "very palatable" and were comparable with control culet prepared from chicken meat. It can be concluded that, turkey meat can be successfully used for preparation of cutlets of acceptable quality.

Table 4 shows the chemical composition of the developed samples. For the quality of minced meat, as well as finished products corresponds to such a rheological indicator as water-binding ability.

During cooking, the free moisture contained in the mushrooms is removed, and bound contains protein and hydrocarbon structures. As a result of fine grinding of the tissues of meat and mushrooms, the particle size decreases, and their total surface increases. Moisture turns into surface-bound moisture; the losses of cutlets during heat treatment were insignificant. The use of mushroom raw materials in the production of cutlets affected the content of the mass fraction of moisture.

Table 4. Chemical composition of the developed samples.

\begin{tabular}{|c|c|c|c|}
\hline Indicator & $\begin{array}{c}\text { Poultry } \\
\text { cutlet } \\
\text { (control) }\end{array}$ & $\begin{array}{c}\text { Cutlet with } \\
\text { mushroom } \\
\text { powder } \\
\text { (sample 1) }\end{array}$ & $\begin{array}{c}\text { Cutlet with } \\
\text { finely ground } \\
\text { mass of } \\
\text { cooked } \\
\text { mushrooms } \\
\text { (sample 2) }\end{array}$ \\
\hline Humidity, \% & 51.2 & 63.2 & 64.8 \\
\hline Protein, \% & 18.3 & 19.2 & 18.9 \\
\hline Fat, \% & 10.2 & 6.4 & 6.8 \\
\hline $\begin{array}{c}\text { Carbohydrate, } \\
\%\end{array}$ & 13.4 & 8.4 & 7.2 \\
\hline Ash, \% & 6.4 & 6.8 & 6.4 \\
\hline $\begin{array}{c}\text { Energy value, } \\
\text { kcal }\end{array}$ & 218.6 & 168 & 165.6 \\
\hline \multicolumn{2}{|c}{} & & \\
\hline
\end{tabular}

\section{Conclusion}

Indicated functional properties of edible cultivated mushrooms allow their use in powdered form in the production of minced meat products. It helps to improve consumer properties, reduce calorie content, as well as produce functional products.

Thus, it was found that to obtain minced meat products of a functional purpose, it is advisable to introduce mushroom into their recipe in an amount of up to $10.0 \%$. It should be noted that the inclusion of mushroom powder due to the partial replacement of bread in the composition of minced meat products helps to reduce their energy value. In addition, due to antioxidant properties, the introduction of mushroom powder into minced meat products will inhibit the oxidation of lipids and prolong their shelf life.

\section{References}

1. P. Mattila, Nutrition, 16, 694-696 (2000)

2. B.A. Wani, J. Med. Plant Res., 24, 2598-2604 (2010)

3. C. Suresh, Int. J. Agric. Sci., 2, 647-651 (2006)

4. X.M. Wang, Food Chem., 151, 279-285 (2014)

5. M. Friedman, Foods, 5, 2-40 (2016)

6. T. Sawangwan, Agric. Nat. Resour., 52, 519-524 (2018)

7. S. Tinrat, Int. J. Pharm. Sci. Rev. Res., 35, 253-262 (2015)

8. I.A. Kutaiba, World J. Pharm. Res., 8, 31-46 (2018)

9. S. E. Mallikarjuna, J. Chem. (2013)

10. M. A. Anandh, Food Sci. Res. J., 11, 17-21 (2020)

11. K. Jo, J. Lee, S. Jung, Korean Food Sci. Anim. Resour., 38, 768-779 (2018)

12. T. Stepanova, N. Kondratjuk, N. Haijuan, Bull. NTU "KhPI", 2, 75-80 (NTU "KhPI", Kharkiv, 2019) 